\title{
VIABILITAS Lactobacillus Sp F213 PADA BERBAGAI MINUMAN SARI BUAH PROBIOTIK SELAMA PENYIMPANAN
}

\author{
Agnes Prina Rini ${ }^{1}$, Komang Ayu Nocianitri ${ }^{2}$, Ni Made Indri Hapsari ${ }^{2}$ ) \\ ${ }^{1}$ Mahasiswa Program Studi Ilmu dan Teknologi Pangan, Fakultas Teknologi Pertanian, Universitas \\ Udayana \\ ${ }^{2}$ Dosen Program Studi Ilmu dan Teknologi Pangan, Fakultas Teknologi Pertanian, Universitas Udayana, \\ Kampus Bukit Jimbaran, Badung-Bali
}

\begin{abstract}
Lactobacillus sp F213 (LbF213) is a lactic acid bacterium isolated from a healthy baby feces, which has been proven as a probiotic bacteria because it is resistant to low $\mathrm{pH}$, bile salts, digestive enzymes, able to aggregate, attach and colonize the intestine, and interact against E. coli. This study aims to determine the viability of probiotic bacteria $\mathrm{LbF} 213$ on various juices during storage. The fruits used in this study were soursop, tamarillo, orange, and pomello. This study used a descriptive comparative method experimental design. The variables observed were total $\mathrm{LAB}$, total sugar, total acid, and $\mathrm{pH}$ tested every 3 days from the 1 st day to the 12th day in the cold storage. The results showed that the total LAB of LbF213 in tamarillo juice during 12 days of storage tend to be constant compared to soursop, orange, and grapefruit juice whereas total LAB, from the first day of storage was $1.37 \times 10^{6} \mathrm{CFU} / \mathrm{ml}$ to 12 th day of storage was $1.81 \times 10^{6} \mathrm{CFU} / \mathrm{ml}$ with a total sugar value $3.13 \%$, total acid value $1.22 \%$, and $\mathrm{pH} 3.95$.
\end{abstract}

Keywords: fruit juice, Lactobacillus sp F123, cold storage

\section{PENDAHULUAN}

Produk pangan fungsional terus berkembang, salah satunya adalah produk probiotik. Produk probiotik adalah produk yang mengandung sejumlah bakteri probiotik di dalamnya, sedangkan probiotik adalah mikroba hidup yang diasup dalam jumlah yang cukup sehingga dapat memberikan manfaat kesehatan bagi inang (Anon, 2001). Menurut Shortt (1999) umumnya probiotik berasal dari bakteri asam laktat (BAL), walaupun tidak semua bakteri asam laktat merupakan probiotik.

Bakteri probiotik lainnya yang sudah diteliti selama beberapa tahun terakhir adalah Lactobacillus sp F213 (LbF213). Bakteri ini diisolasi dari feses bayi sehat, yang telah terbukti berperan sebagai probiotik (Sujaya et al., 2010). Aspek fungsional probiotik ini dapat melekat pada epitel saluran pencernaan untuk mencegah diare dan diduga dapat menstimulasi sistem imun (Artati, 2009), menghidrolisis garam empedu dan berpotensi menurunkan kolesterol darah (Jemarut, 2009), serta mencegah konstipasi (Sujaya et al., 2013). LbF213 memiliki potensi yang baik bila dikonsumsi oleh manusia, namun bakteri ini masih belum diaplikasikan ke produk pangan sehingga sulit dikonsumsi oleh masyarakat. Aplikasi bakteri LbF213 ke dalam minuman sari buah menjadi minuman probiotik sari buah dapat menjadi solusi dari permasalahan tersebut.

Sari buah memiliki potensi untuk dikembangkan menjadi produk minuman probiotik. Menurut Ding dan Shah (2008) sari buah memiliki kadar gula, vitamin, dan mineral yang tinggi yang dapat dimanfaatkan oleh bakteri probiotik. Pengaplikasian bakteri ke dalam minuman sari buah memiliki kendala di mana belum diketahuinya viabilitas bakteri LbF213 di dalam sari buah. Menurut Wibowo (2011) syarat pertumbuhan mikroba adalah terdapatnya nutrien, tidak terdapatnya inhibitor, dan kondisi fisikokimia yang mendukung. Setiap buah memiliki kandungan dan karakteristik yang berbedabeda, seperti kandungan nutrien, kandungan antimikroba dan kadar pH-nya. 
Sirsak (Annona muricata Linn), terung belanda (Solanum betaceum Cav), jeruk bali (Citrus maxima. Merr), dan jeruk siam (Citrus nobilis var. microcarpa) merupakan buahbuahan yang sudah dikenal dan dibudidayakan di Bali. Sirsak merupakan salah satu buah yang memiliki berbagai kandungan antioksidan di dalamnya, diantaranya vitamin C, flavonoid, tannin, fenol, alkaloid, glikosida, saponin dan terpenoid (Vinothini dan Growhter, 2016). Terung belanda memiliki kandungan antioksidan antosianin dan karotenoid yang tinggi, selain itu terdapat juga tannin, alkaloid, dan flavonoid (Asih et al., 2015). Jeruk bali mengandung vitamin $\mathrm{B}$, provitamin $\mathrm{A}$, vitamin B1, vitamin B2, dan asam folat. Jeruk bali juga memiliki kandungan bioaktif lain seperti alkaloid, asam amino, flavonoid, karotenoid, kumarin, monoterpene, sesquiterpen, dan steroid (Vijaylakshmi dan Radha, 2015). Jeruk siam memiliki kandungan vitamin C, alkaloid, flavonoid, fenol, triterpenoid, saponin, tannin, kumarin, dan steroid (Ghafar, 2010).

Menurut Abdillah (2006) tumbuhan yang berpotensi sebagai antibakteri umumnya memiliki senyawa golongan flavonoid yaitu jenis flavon, flavonol, flavononon, tanin, alkanoid, dan saponin. Baik sirsak, terung belanda, jeruk bali dan jeruk siam memiliki karakteristik dan kandungan antibakteri tertentu, oleh karena itu perlu dilakukan penelitian untuk mengetahui buah mana yang tidak menghambat pertumbuhan bakteri probiotik LbF213, sehingga nantinya buah tersebut dapat diaplikasikan menjadi sari buah probiotik yang potensial bagi kesehatan tubuh.

\section{METODE PENELITIAN}

\section{Tempat dan Waktu Penelitian}

Penelitian ini dilaksanakan di UPT.

Laboratorium Terpadu Biosains dan

Bioteknologi Universitas Udayana dan Laboratorium Biokimia dan Nutrisi Fakultas Teknologi Pertanian Universitas Udayana, Bukit Jimbaran. Penelitian ini dilakukan pada bulan Juli hingga November 2018.

\section{Bahan dan Alat}

Bahan yang digunakan dalam penelitian ini adalah isolat LbF213 (koleksi UPT Laboraturium Terpadu Biosain dan Bioteknologi Universitas Udayana), buah sirsak, buah terung belanda, buah jeruk siam, buah jeruk bali (dibeli di Pasar Swalayan Tiara Dewata di Jalan Mayjen Sutoyo No. 55, Dauh Puri, Denpasar, Bali), air mineral, alkohol 96\%, MRS A (Pronadisa), MRS B (Oxoid), aquades, $\mathrm{NaCl} 0,85 \%$, gliserol, kristal violet, larutan lugol, pewarna safranin, larutan $\mathrm{H}_{2} \mathrm{O}_{2}$, larutan buffer $\mathrm{pH} 4,7$ dan 10 , $\mathrm{NaOH} 0,1 \mathrm{~N}$, phenolphtalein $1 \%$, glukosa standar, Nelson A, Nelson B, HCl 4 N, larutan arsenomolybdat, alumunium foil, metanol dan tisu.

Peralatan yang digunakan dalam penelitian ini adalah jar kaca ukuran 100ml, baskom, blender, pemeras jeruk, pisau, talenan, timbangan, kain saring, gelas ukur plastic ukuran $1 \mathrm{~L}$ botol plastic ukuran $1 \mathrm{~L}$, waterbath, jar kaca ukuran 2 L, gelas ukur, autoklaf, tip $100 \mu \mathrm{L}$, tip $1000 \mu \mathrm{L}$, sentrifuge tube, erlemeyer (pyrex), gelas beaker, pipet mikro, vortex, sentrifuge, show case, bunsen, cawan petri, laminar air flow, tabung reaksi (pyrex), batang bengkok, inkubator, jarum ose, spektrofotometer, pHmeter, timbangan analitik, mikroskop, pipet volume, buret, labu ukur, magnetik stirer, gelas objek, freezer, dan kompor listrik.

\section{Pelaksanaan Penelitian}

1. Penyegaran dan konfirmasi isolat (Suryani et al., 2010)

Bakteri LbF213 dilakukan penyegaran dengan cara diambil $100 \mu L$ stok isolat yang disimpan dalam gliserol $30 \%$ pada suhu $-20^{\circ} \mathrm{C}$, lalu diinokulasi pada $5 \mathrm{ml}$ media MRS Broth dan diinkubasi pada suhu $37^{\circ} \mathrm{C}$ selama 24 jam. Hasil positif ditunjukkan dengan munculnya kekeruhan pada media. Setelah penyegaran, dilakukan konfirmasi isolat melalui uji katalase, pewarnaan gram dan uji gas. Uji katalase dilakukan dengan meneteskan isolat pada gelas objek, kemudian ditetesi dengan dua tetes larutan $\mathrm{H}_{2} \mathrm{O}_{2}$, dan diamati gelembung yang timbul. Hasil positif ditunjukkan oleh timbulnya gelembung udara 
$\left(\mathrm{O}_{2}\right)$ yang dihasilkan dari degradasi $\mathrm{H}_{2} \mathrm{O}_{2}$ oleh enzim - enzim katalase.

Pewarnaan gram dilakukan dengan meneteskan isolat pada gelas objek kemudian difiksasi di atas bunsen dan diwarnai dengan kristal violet selama 1 menit, kemudian ditetesi dengan larutan lugol selama 1 menit. Selanjutnya gelas objek ditetesi alkohol selama 1 menit dan terakhir diwarnai dengan pewarna safranin selama 5 detik. Sel bakteri yang telah diwarnai, dikeringkan dan diamati dibawah mikroskop.

Uji gas dilakukan dengan metode hot loop, dengan cara memasukkan jarum ose panas ke dalam suspensi biakan BAL. Hasil positif ditandai dengan terbentuknya gas $\mathrm{CO}_{2}$ dari hasil metabolisme glukosa. 2. Pembuatan Sari Buah

Proses pembuatan sari buah sirsak dan sari buah terung belanda berbeda dengan proses pembuatan sari buah jeruk siam dan sari buah jeruk bali. Perbedaan ini disebabkan karena tekstur dan kadar air pada buah. Buah sirsak dan buah terung belanda memiliki karakteristik dan tekstur yang mirip sehingga proses pembuatan sari buahnya memiliki metode yang serupa. Pembuatan sari buah sirsak atau sari buah terung belanda diawali dengan proses sortasi, dipilih buah yang sudah masak. Buah sirsak dibelah menjadi dua bagian dan dipisahkan kulit dan biji buah dengan daging buahnya, sedangkan pada terung belanda buah dikupas terlebih dahulu lalu buah dipotong sebesar $\pm 2 \mathrm{~cm}$. Masingmasing buah ditambahkan air dengan perbandingan buah dan air 1:1. Tahap berikutnya buah dihancurkan dengan menggunakan blender. Tahap selanjutnya dilakukan penyaringan pada kedua sari buah dengan menggunakan 2 lapis kain saring, sehingga dihasilkan sari buah tanpa ampas. Tahap berikutnya masing-masing sari buah dipasteurisasi dengan suhu $80^{\circ} \mathrm{C}$ selama 4,5 menit dengan menggunakan waterbath. Terakhir masing-masing sari buah yang sudha dipasteurisasi dimasuka ke dalam botol.

Jeruk siam atau jeruk bali yang digunakan adalah jeruk yang sudah masak. Tahap pertama jeruk disortasi, dipilih jeruk dalam kondisi baik. Tahap berikutnya jeruk dibelah menjadi dua bagian dan dipisahkan daging dengan bijinya. Selanjutnya pada jeruk siam dilakukan pemerasan dengan alat pemeras jeruk, sedangkan pada jeruk bali dipotong-potong terlebih dahulu lalu dihancurkan dengan blender, sehingga pada kedua jenis buah dihasilkan masing-masing sari buah. Tahap berikutnya dilakukan penyaringan sehingga dihasilkan sari buah tanpa ampas. Sari buah jeruk siam dan jeruk bali dipasteurisasi selama 4,5 menit dengan suhu $80^{\circ} \mathrm{C}$ menggunakan waterbath. Masingmasing sari buah dimasukan ke dalam botol.

\section{Inokulasi Bakteri}

Diambil sebanyak $100 \mu \mathrm{l}$ stok kultur LbF213 dalam gliserol dan dimasukkan ke dalam $5 \mathrm{ml}$ media MRSB, lalu diinkubasi selama 24 jam pada $37^{\circ} \mathrm{C}$. Setelah inkubasi, media tersebut diamati, hasil positif ditunjukan dengan kekeruhan pada media, tabung reaksi tersebut kemudian di-vortex. Diambil sebanyak $100 \mu$ l inukulum dalam MRSB dan direkultur ke dalam $50 \mathrm{ml}$ MRSB, lalu diinkubasi kembali selama 24 jam pada $37^{\circ} \mathrm{C}$. Setelah inkubasi, media tersebut diamati, hasil positif ditunjukan dengan kekeruhan pada media dengan nilai $\mathrm{OD}_{660}$ sebesar 2,183. Tahap berikutnya diambil sebanyak $40 \mathrm{ml}$ inukulum dalam MRSB dan dipindahkan ke dalam centrifuge tube untuk disentrifugasi pada kecepatan $5000 \mathrm{rpm}$ selama 10 menit. Setelah disentrifugasi, akan terbentuk endapan kultur mikroba pada dasar tabung eppendorf. MRSB di atas endapan kultur tersebut dibuang, sedangkan sel yang tertinggal dicuci sebanyak 3 kali. Pencucian sel dilakukan dengan cara menambahkan larutan saline ke dalam centrifuge tube berisi endapan kultur LbF213 lalu divorteks, selanjutnya centrifuge tube disentrifugasi pada kecepatan 5000 rpm selama 10 menit, dan membuang supernatan yang terbentuk setelah proses sentrifugasi. Larutan saline sisa dari pencucian terakhir dibuang, kemudian diambil sebanyak $40 \mathrm{ml}$ larutan saline dan dimasukkan ke dalam tabung centrifuge tube. Centrifuge tube berisi inokulum tersebut divortex dan diinokulasi $1 \mathrm{ml}$ kultur $(2,46 \mathrm{x}$ $10^{8} \mathrm{CFU} / \mathrm{ml}$ ) ke dalam $80 \mathrm{ml}$ sari buah kemudian dikocok. Sari buah tersebut kemudian disimpan pada suhu $4^{\circ} \mathrm{C}$. 


\section{Rancangan Percobaan dan Analisis Data}

Penelitian ini menggunakan rancangan percobaan metode deskriptif komparatif. Data disajikan dalam bentuk tabel, grafik dan gambar. Perlakuan ini diulang sebanyak tiga kali sehingga diperoleh 60 unit percobaan.

\section{Parameter yang Diamati}

Parameter yang diamati pada penelitian ini meliputi total BAL (Fardiaz, 1993), total gula dengan metode NelsonSomogyi (Sudarmadji et al., 1996), total asam laktat dengan metode titrasi netralisasi (Sudarmadji et al., 1996), dan $\mathrm{pH}$ dengan alat $\mathrm{pH}$ meter (AOAC, 1998).

\section{HASIL DAN PEMBAHASAN}

\section{Total BAL}

Hasil analisis menunjukan nilai ratarata total BAL berbagai sari buah probiotik mengalami perubahan selama penyimpanan. Nilai rata-rata total BAL berbagai sari buah probiotik dapat dilihat pada Tabel 1 dan perubahan total BAL sari buah probiotik selama penyimpanan dapat dilihat pada Gambar 1.

Tabel 1. Nilai Rata-Rata Total BAL Sari Buah Probiotik Selama Penyimpanan

\begin{tabular}{lccccc}
\hline \multirow{2}{*}{ Jenis Sari Buah } & \multicolumn{5}{c}{ Peyimpanan hari ke- } \\
\cline { 2 - 6 } & $\mathbf{0}$ & $\mathbf{3}$ & $\mathbf{6}$ & $\mathbf{9}$ & $\mathbf{1 2}$ \\
\hline Sirsak & $1,55 \times 10^{6}$ & $8,20 \times 10^{5}$ & $7,10 \times 10^{5}$ & $5,20 \times 10^{5}$ & $4,30 \times 10^{5}$ \\
Terung Belanda & $1,37 \times 10^{6}$ & $1,61 \times 10^{6}$ & $1,81 \times 10^{6}$ & $1,47 \times 10^{6}$ & $1,80 \times 10^{6}$ \\
Jeruk Siam & $2,27 \times 10^{5}$ & $1,25 \times 10^{5}$ & $1,70 \times 10^{4}$ & $2,90 \times 10^{4}$ & $9,70 \times 10^{3}$ \\
Jeruk Bali & $1,26 \times 10^{5}$ & $1,25 \times 10^{5}$ & $1,70 \times 10^{4}$ & $2,80 \times 10^{4}$ & $9,60 \times 10^{3}$ \\
\hline
\end{tabular}

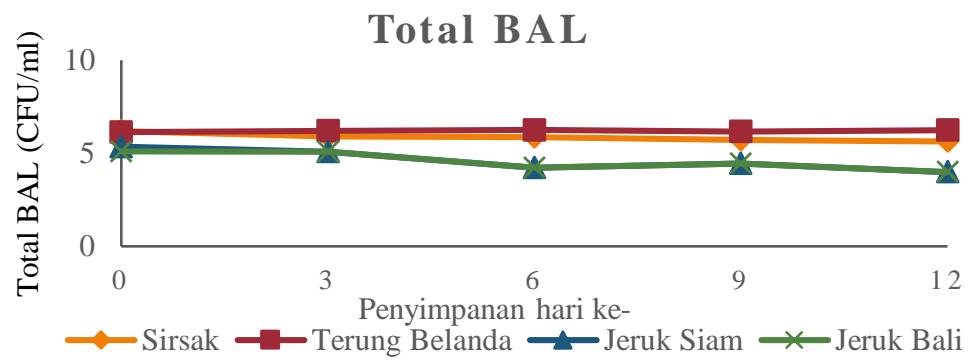

Gambar 1. Grafik Perubahan Total BAL Sari Buah Probiotik Selama Penyimpanan

Gambar 1. Menunjukan pertumbuhan Lactobacillus sp F213 yang berbeda-beda pada berbagai sari buah selama penyimpanan suhu $4^{\circ} \mathrm{C}$. Pertumbuhan LbF213 pada sari buah sirsak mengalami penurunan, pada sari buah terung belanda cenderung stabil, dan pada jeruk siam dan jeruk bali mengalami penurunan. Pertumbuhan BAL pada sari buah sirsak mengalami penurunan 1 log pada penyimpanan hari ke-3 yaitu dari $1,55 \times 10^{6}$ CFU $/ \mathrm{ml}$ menjadi $8,2 \times 10^{5} \mathrm{CFU} / \mathrm{ml}$, setelah itu total BAL pada sirsak konstan hingga hari ke12 yaitu sebesar $4,3 \times 10^{5} \mathrm{CFU} / \mathrm{ml}$. Pertumbuhan BAL pada buah terung belanda mulai dari penyimpanan hari ke-0 hingga hari ke-12 cenderung konstan yaitu dari $1,37 \times 10^{6}$ $\mathrm{CFU} / \mathrm{ml}$ hingga $1,8 \times 10^{6} \mathrm{CFU} / \mathrm{ml}$. Total BAL pada jeruk siam mengalami penurunan sebesar $2 \log$ selama penyimpanan, yaitu dari 2.27x $10^{5} \mathrm{CFU} / \mathrm{ml}$ hingga $9.7 \times 10^{3} \mathrm{CFU} / \mathrm{ml}$. Sari buah jeruk bali mengalami penurunan total BAL selama penyimpanan suhu rendah dari penyimpanan hari ke-0 yaitu sebesar $1.26 \times 10^{5} \mathrm{CFU} / \mathrm{ml}$ hingga hari ke-12 yaitu sebesar $9.6 \times 10^{3} \mathrm{CFU} / \mathrm{ml}$.

Pertumbuhan LbF213 pada sari buah sirsak mengalami hambatan pada penyimpanan hari ke-3, namun cenderung stabil hingga penyimpanan hari ke-12. Hal ini menunjukan sari buah sirsak tidak memiliki aktivitas antimikroba yang tinggi terhadap LbF213. Hal ini sejalan dengan penelitian Saraswati (2013) yang menunjukan tidak terjadinya aktivitas antibakteri pada ekstrak daging buah sirsak konsentrasi $5 \%$ terhadap Staphylococcus aureus. 
Sari buah terung belanda merupakan media yang paling cocok untuk pertumbuhan LbF213, hal ini dapat dilihat dari jumlah total BAL yang cenderung konstan selama penyimpanan 12 hari. Menurut penelitian Gannasin (2015) terung belanda mengandung prebiotik hidrokoloid yang terdapat pada biji dan daging buah. Ekstrak hidrokoloid pada terung belanda terbukti dapat meningkatkan jumlah Lactobacillus selama fermentasi 24 jam.

Pertumbuhan LbF123 terhambat pada sari buah jeruk siam dan jeruk bali, hal ini ditandai dengan penurunan jumlah total BAL sebesar 2 log selama penyimpanan suhu rendah. Jeruk siam merupakan buah yang mengandung berbagai senyawa antibakteri di dalamnya seperti senyawa fenolik (karvakrol, timol, dan eugenol), alkaloid, triterpenoid, saponin, tannin, steroid, dan glikosida. Menurut Davidson dan Naidu (2000) kandungan fenolik (karvakrol, timol, dan eugenol) pada jeruk memiliki aktivitas antibakteri yang tinggi pada bakteri Gram (+), Gram (-), dan jamur. Kandungan fenolik dapat merusak kerja membran sitoplasma sel bakteri dan menghilangkan Proton Motive Force (PMF), sehingga menghambat produksi energi dan biosintesis protein. Menurut penelitian Zaika dan Kissinger (1981) tanaman oregano yang sebagian besar megandung senyawa karvakrol dan timol menghambat pertumbuhan Lactobacillus plantarum selama 7 hari fermentasi.

Saponin, tannin, steroid, dan glikosida pada jeruk siam juga memiliki aktivitas antimikroba pada bakteri Gram (+) dan Gram (-) seperti Staphylococcus aureus, Escherichia coli, dan Bacillus cereus (Soetan et al, 2006).

Pertumbuhan LbF213 pada jeruk bali juga terhambat selama penyimpanan, hal ini kemungkinan disebabkan oleh kandungan antimikroba pada jeruk bali. Jeruk bali memiliki kandungan flavonoid yang tinggi yaitu sebesar $1.602,7 \mathrm{mg} / \mathrm{kg}$. Flavonoid pada jeruk bali dapat menghambat pertumbuhan bakteri Bacillus subtilis dan Staphylococcus aureus (Sahlan, 2018). Menurut penelitian Yathiender (2017) ekstrak jeruk bali dapat menghambat pertumbuhan Escherichia coli dan Klebsiella pneumoniae.

\section{Total Gula}

Hasil analisis menunjukan bahwa total gula pada berbagai sari buah probiotik mengalami perubahan selama penyimpanan. Nilai rata-rata total gula berbagai sari buah dapat dilihat pada Tabel 2 dan perubahan total gula pada sari buah probiotik selama penyimpanan dapat dilihat pada Gambar 2 .

Tabel 2. Nilai Rata-Rata Total Gula Sari Buah Probiotik Selama Penyimpanan

\begin{tabular}{lccccc}
\hline \multicolumn{1}{c}{ Jenis Sari Buah } & \multicolumn{5}{c}{ Peyimpanan hari ke- } \\
\cline { 2 - 6 } & $\mathbf{0}$ & $\mathbf{3}$ & $\mathbf{6}$ & $\mathbf{9}$ & $\mathbf{1 2}$ \\
\hline Sirsak & $3,80 \pm 0,21$ & $3,91 \pm 0,32$ & $4,10 \pm 0,06$ & $4,68 \pm 0,31$ & $4,22 \pm 0,20$ \\
Terung Belanda & $2,79 \pm 0,08$ & $2,67 \pm 0,22$ & $2,74 \pm 0,25$ & $3,36 \pm 0,36$ & $3,13 \pm 0,28$ \\
Jeruk Siam & $4,84 \pm 0,11$ & $4,93 \pm 0,07$ & $4,83 \pm 0,06$ & $4,64 \pm 0,10$ & $4,77 \pm 0,08$ \\
Jeruk Bali & $4,37 \pm 0,09$ & $4,73 \pm 0,11$ & $4,76 \pm 0,17$ & $4,96 \pm 0,08$ & $4,66 \pm 0,12$ \\
\hline
\end{tabular}

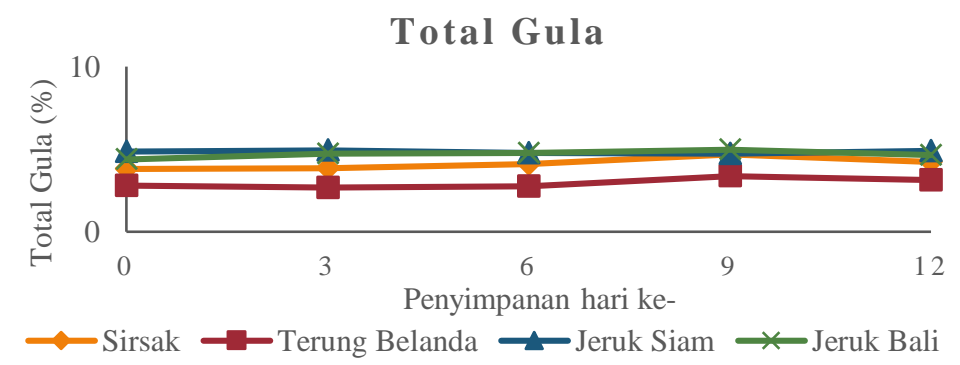

Gambar 2. Grafik Perubahan Total Gula Sari Buah Probiotik Selama Penyimpanan 
Gambar 2 menunjukan nilai ratarata total gula berbagai sari buah selama penyimpanan. Sari buah sirsak, terung belanda, jeruk siam, jeruk bali memiliki TSS yang seragam yaitu sebesar 5,4 . Total gula sari buah sirsak mengalami peningkatan dari penyimpanan hari ke-0 sebesar $3,80 \%$ hingga penyimpanan hari ke9 sebesar $4,68 \%$, kemudian mengalami penurunan pada hari ke-12 yaitu sebesar $4,22 \%$. Sari buah terung belanda mengalami penurunan total gula pada penyimpanan hari ke-3 yaitu dari $2,79 \%$ menjadi 2,69\%, kemudian mengalami peningkatan pada penyimpanan hari ke-6 dan ke-9 masing-masing sebesar $2,74 \%$ dan $3,36 \%$, kemudian mengalami penurunan kembali pada hari ke-12 yaitu sebesar 3,13\%. Nilai total gula sari buah jeruk siam yang dihasilkan cenderung konstan selama 12 hari penyimpanan. Jeruk siam memiliki total gula pada penyimpanan hari ke-0 sebesar 4,84\% hingga penyimpanan hari ke12 sebesar $4,77 \%$. Jeruk bali menghasilkan nilai total gula pada penyimpanan hari ke-0 sebesar 4,37\% hingga penyimpanan hari ke12 sebesar 4,66\%. Total gula yang dihasilkan dari keempat sari buah probiotik mengalami peningkatan selama penyimpanan, hal ini kemungkinan disebabkan oleh proses hidrolisis alami sari buah. Hidrolisis adalah proses pemecahan senyawa kompleks menjadi senyawa sederhana dengan bantuan air. Pati pada sari buah dipecah menjadi glukosa.
Asam yang terdapat pada sari buah berperan sebagai katalisator pada proses hidrolisis.

Menurut Wibawa (2014) baik asam kuat dan asam lemah dapat berperan sebagai katalisator. Semakin rendah nilai $\mathrm{pH}$ pada asam yang digunakan pada proses hidrolisis, maka semakin tinggi glukosa yang dihasilkan (Wulandari, 2017). Buah sirsak terung belanda, jeruk siam, dan jeruk bali memiliki nilai $\mathrm{pH}$ yang cukup tinggi yaitu berkisar 3-4. Proses hidrolisis terjadi dengan pemecahan ikatan $\alpha$-D-glukosa dari molekul pati serta terjadi pelemahan struktur granula pati. Asam juga dapat memecah hemiselulosa menjadi monomermonomer gula seperti arabinose, galaktosa, dan glukosa (Sun dan Cheng, 2005). Hasil penelitian ini juga sesuai dengan penelitian Nuklaekul (2011) yang menunjukan terjadinya peningkatan nilai total gula sari buah probiotik yang disimpan selama 6 minggu pada suhu $4^{\circ} \mathrm{C}$.

\section{Total Asam}

Hasil analisis menunjukan nilai total asam berbagai sari buah yang berbedabeda selama penyimpanan. Nilai rata-rata total asam sari buah probiotik selama penyimpanan dapat dilihat pada Tabel 3 dan perubahan total asam pada sari buah probiotik selama penyimpanan dapat dilihat pada Gambar 3.

Tabel 3. Nilai Rata-Rata Total Asam Sari Buah Probiotik Selama Penyimpanan

\begin{tabular}{lccccc}
\hline \multicolumn{1}{c}{ Jenis Sari Buah } & \multicolumn{5}{c}{ Peyimpanan hari ke- } \\
\cline { 2 - 6 } & $\mathbf{0}$ & $\mathbf{3}$ & $\mathbf{6}$ & $\mathbf{9}$ & $\mathbf{1 2}$ \\
\hline Sirsak & $0,45 \pm 0,07$ & $0,44 \pm 0,03$ & $0,39 \pm 0,02$ & $0,38 \pm 0,02$ & $0,41 \pm 0,03$ \\
Terung Belanda & $1,28 \pm 0,14$ & $1,34 \pm 0,17$ & $1,16 \pm 0,04$ & $1,11 \pm 0,00$ & $1,22 \pm 0,04$ \\
Jeruk Siam & $0,62 \pm 0,02$ & $0,63 \pm 0,02$ & $0,74 \pm 0,02$ & $0,70 \pm 0,04$ & $0,75 \pm 0,03$ \\
Jeruk Bali & $0,61 \pm 0,05$ & $0,55 \pm 0,07$ & $0,59 \pm 0,04$ & $0,65 \pm 0,03$ & $0,67 \pm 0,02$ \\
\hline
\end{tabular}




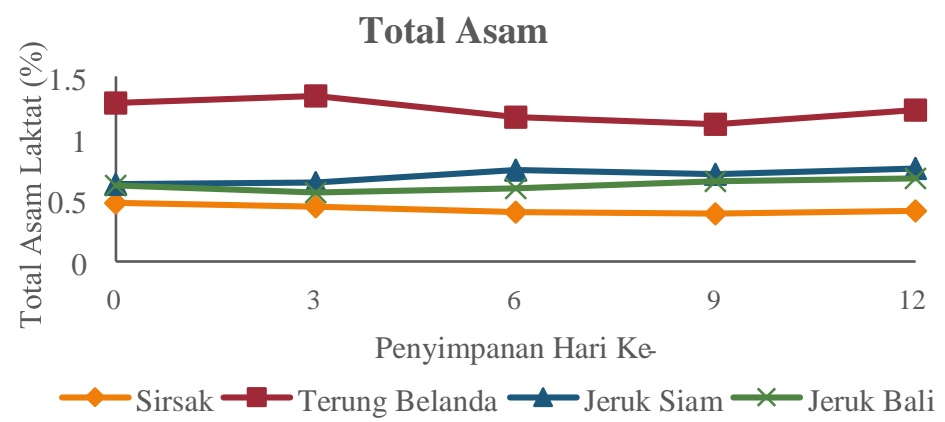

Gambar 3. Grafik Nilai Rata-Rata Total Asam Sari Buah Probiotik Selama Penyimpanan

Gambar 3 menunjukan rata-rata nilai total asam berbagai sari buah probiotik yang disimpan selama 12 hari pada suhu rendah. Semua sari buah menghasilkan nilai total asam yang cenderung konstan selama penyimpanan suhu rendah. Sari buah sirsak menghasilkan nilai total asam $0,45 \%$ pada hari ke-0 hingga $0,41 \%$ pada hari ke-12. Sari buah terung belanda menghasilkan nilai total asam sebesar $1,28 \%$ pada hari ke-0 hingga $1,22 \%$ pada hari ke-12. Sari buah jeruk siam menghasilkan nilai total asam sebesar $0,62 \%$ pada hari ke-0 hingga $0,75 \%$ pada hari ke-12. Sari buah jeruk bali menghasilkan nilai total asam sebesar $0,61 \%$ pada hari ke-0 hingga $0,67 \%$ pada penyimpanan hari ke-12.

Nilai asam laktat yang cenderung konstan pada berbagai sari buah probiotik selama penyimpanan kemungkinan disebabkan oleh terhambatnya metabolisme BAL untuk merombak gula menjadi asam-asam laktat akibat penyimpanan suhu rendah. Selama penyimpanan suhu rendah $\left(4^{\circ} \mathrm{C}-10^{\circ} \mathrm{C}\right)$ pertumbuhan dan metabolisme bakteri asam laktat terjadi sangat lambat, hal ini menyebabkan sedikitnya perombakan gula menjadi asam laktat (Ayuti et al., 2016). Hasil analisis total asam juga sejalan dengan analisis total BAL dan analisis $\mathrm{pH}$ yang masing-masing menunjukan nilai yang cenderung konstan selama 12 hari penyimpanan suhu rendah, hal ini menunjukan terhambatnya proses metabolisme BAL pada sari buah probiotik.

\section{Derajat Keasaman (pH)}

Hasil analisis menunjukan nilai rata-rata derajat keasaman $(\mathrm{pH})$ pada berbagai sari buah probiotik yang mengalami perubahan. Nilai rata-rata $\mathrm{pH}$ sari buah probiotik sirsak, terung belanda, jeruk bali, dan jeruk siam dapat dilihat pada Tabel 4 dan perubahan total asam pada sari buah probiotik selama penyimpanan dapat dilihat pada Gambar 4.

Tabel 4. Nilai rata-rata pH pada Sari Buah Probiotik Selama Penyimpanan

\begin{tabular}{lccccc}
\hline \multicolumn{5}{c}{ Jenis Sari Buah } & \multicolumn{5}{c}{ Peyimpanan hari ke- } \\
\cline { 2 - 6 } & $\mathbf{0}$ & $\mathbf{3}$ & $\mathbf{6}$ & $\mathbf{9}$ & $\mathbf{1 2}$ \\
\hline Sirsak & $3,84 \pm 0,07$ & $3,68 \pm 0,02$ & $3,62 \pm 0,02$ & $3,72 \pm 0,03$ & $3,87 \pm 0,03$ \\
Terung Belanda & $3,69 \pm 0,37$ & $3,75 \pm 0,03$ & $3,63 \pm 0,03$ & $3,84 \pm 0,04$ & $3,95 \pm 0,03$ \\
Jeruk Siam & $3,48 \pm 0,00$ & $3,48 \pm 0,00$ & $3,47 \pm 0,00$ & $3,49 \pm 0,00$ & $3,40 \pm 0,17$ \\
Jeruk Bali & $3,63 \pm 0,00$ & $3,62 \pm 0,00$ & $3,61 \pm 0,00$ & $3,63 \pm 0,00$ & $3,63 \pm 0,00$ \\
\hline
\end{tabular}




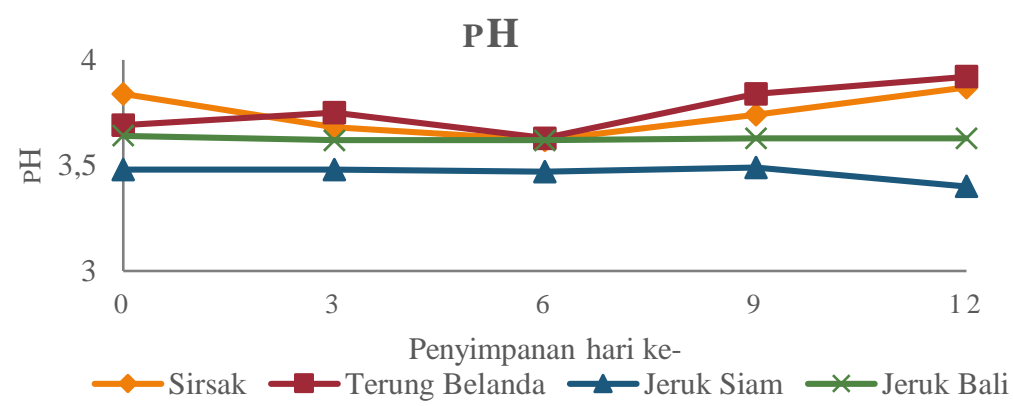

Gambar 4. Grafik Nilai Rata-Rata pH Sari Buah Probiotik Selama Penyimpanan

Gambar 4 menunjukan nilai ratarata $\mathrm{pH}$ sari buah sirsak, terung belanda, jeruk siam, dan jeruk bali yang mengalami perubahan selama penyimpanan suhu rendah dari hari ke-0 hingga hari ke-12.

Sari buah sirsak mengalami penurunan $\mathrm{pH}$ pada hari ke-3 yaitu dari 3,84-3,68, kemudian terjadi peningkatan nilai $\mathrm{pH}$ pada hari ke-12 yaitu sebesar 3,87 . Nilai $\mathrm{pH}$ sari buah probiotik terung belanda mengalami penurunan pada penyimpanan hari ke-6 dari 3,69-3,63, kemudian terjadi peningkatan dari hari ke-6 hingga hari ke-12 yaitu berkisar antara 3,63-3,92. Sari buah probiotik jeruk siam memiliki nilai $\mathrm{pH}$ dari penyimpanan hari ke-0 sebesar 3,48 hingga penyimpanan hari ke-12 3,40. Sari buah probiotik jeruk bali memiliki nilai $\mathrm{pH}$ yang cenderung konstan dari penyimpanan hari ke- 0 hingga hari ke-12 yaitu berkisar antara 3,63-3,63. Hasil ini sesuai dengan penelitian Akpeji dan AdebayoTayo (2016) mengenai viabilitas BAL pada sari buah nanas yang menghasilkan nilai $\mathrm{pH}$ yang berubahubah selama penyimpanan 4 minggu pada suhu rendah.

Hasil analisis pH pada berbagai sari buah yang cenderung konstan sesuai dengan hasil analisis total asam yang menunjukan keempat sari buah memiliki nilai total asam yang cenderung konstan. Nilai total asam yang cenderung konstan disebabkan karena terhambatnya proses metabolisme BAL untuk memecah gula menjadi asam laktat, hal ini yang menyebabkan sedikitnya penurunan nilai $\mathrm{pH}$.

\section{KESIMPULAN DAN SARAN Kesimpulan}

Berdasarkan penelitian yang telah dilakukan, dapat disimpulkan:

1. Sari buah jeruk siam dan jeruk bali menghambat viablitas Lactobacillus sp F123 karena selama 12 hari penyimpanan total BAL pada sari buah menurun sebanyak 2 log. Sari buah sirsak menghambat viablitas Lactobacillus sp F123 karena terjadi penurunan nilai total BAL sebanyak 1 log pada penyimpanan hari ke-3.

2. Sari buah terung belanda merupakan media yang paling cocok untuk pertumbuhan Lactobacillus sp F123, karena selama 12 hari penyimpanan nilai total BAL cenderung stabil.

\section{Saran}

Perlu dilakukan penambahan gula dan fermentasi terhadap sari buah sebelum disimpan pada suhu rendah 
untuk meningkatkan total BAL pada sari buah.

\section{DAFTAR PUSTAKA}

Abdillah, A. 2006. Aktivitas Antiproliferasi Ekstrak Air Daun Sisik Naga (Pyrrosia nummularifolia (Sw.) Ching) Terhadap Sel Lestari Tumor HeLa secara In Vitro. Skripsi. Institut Pertanian Bogor, Bogor.

Akpeji, S. C., dan B. C. Adebayo-Tayo. 2017. Production and Properties of Probioticic Soursop Juice Using Pediococcus pentosaceus LBF2 as Starter. International Journal of Biochemistry Research \& Review. Vol 17 No 2. Pp: 1-10.

Anonimus, 2001. FHO/WHO. Joint Expert Consultation of Health and Nutritional Properties of Probiotics in Food Including Powder Milk with Lactic Acid Bacteria. http://www.who.int. Diakses tanggal 25 Mei 2018.

AOAC. 1998. Official Methods of Analysis of AOAC. The Association of Analytical Chemist, 16th ed. Airlington: VA.

Artati, 2009. Karakteristik Probiotik dari Lactobacillus sp F212 dan Lactobacillus sp F213 Serta Kemampuan Komeptisi Perlekatannya dengan Escherichia coli O157 pada Media Enterosit Mencit. Skripsi. Universitas Udayana, Bali.

Asih, I. A. R. A., I. W. Sudiarta dan A. A. W. Suci. 2015. Aktivitas Antioksidan Senyawa Golongan
Flavonoid Ekstrak Etnol dari Daging Buah Terong Belanda (Solanum betaceum Cav.). Jurnal Kimia 9 (1): 35-40.

Ayuti, S. R., Nurliana, Yurliasni, Sugito dan Darmawi. 2016. Dinamika Pertumbuhan Lactobacillus casei dan Karakteristik Susu Fermentasi Berdasarkan Suhu dan Lama Penyimpanan. Agripet. Vol 16. No 1.

Ding, W. K. dan N. P. Shah. 2008. Survival of Free and Microencapsulated Probiotic Bacteria in Orange and Apple Juices. International Food Journal 15 (2): 219-232

Davidson dan A. S. Naidu. 2000. Natural Food Antimicrobial System. CRC Press. Califronia State Polytechnic University Pomona, Califronia.

Diniyah, N., A. Subagio, dan M. Fauzi., 2013. Produksi Minuman Fungsional Sirsak (Anona muricata. Linn) dengan Fermentasi Bakteri Asam Laktat. Jurnal Teknotan 2 (7): 10071012.

Fardiaz, S. 2013. Perhitungan Total Popoulasi BAL pada Yoghurt. Diakses melalui e-jounal 7-8 pada 14 Maret 2018.

Fardiaz, S. 1989. Analisis Mikrobiologi Pangan. PT. RajaGrafindo Persada, Jakarta

Gannasin, S. P., S. Mustafa, N. M. Adzahan, dan K. Muhammad. 
2015. In Vitro Prebiotic Activities of tamarillo (Solanum betaceum Cav.) hydrocolloids. Journal of Functional Foods (19):10-19.

Ghafar, M. F. A. 2010. Flavoid, Hespiridin, Total Phenolic Content and Antioxidan Activities from Citrus Species. African Journal of Biotechnology 9(3): 326-330.

Jemarut, 2009. Total Bakteri Anaerob dan Kadar Kolesterol Darah pada Tikus Puti (Rattus norvegicus) yang Diberikan Probiotik Lactobacillus sp F213. Skripsi.

Universitas Udayana, Bali.

Mulyawanti, I. dan K. T. Dewandari. 2010. Studi Penerapan HACCP Pada Pengolahan Sari Buah Jeruk Siam. Jurnal Standarisasi 1(12): 43-49.

Nasution, F. S. 2012. Identifikasi dan Karakterisasi Bakteri Asam Laktat pada Kotoran Ayam Broiler sebagai Agensia Probiotik. Skripsi.

Universitas Negeri Medan, Medan.

Nuklaekul, S., I. Salmeron dan D. Charalampoupolos. 2011. Investigation of the Factors Influencing the Survivor of Bifidobacterium longum in Model Acidic Solution and Fruit Juices. Food Chemistry. Vol 129. Hal 1037-1044.
Nuraida, L., S. Winarti, Hana, dan E. Pradimurti. 2011. Evaluasi Invitro

Terhadap Kemampuan Isolat Bakteri Asam Laktat Asal Air Susu Ibu untuk Mengasimilasi Kolesterol dan Mendekonjugasi

Garam Empedu. Jurnal Teknologi Industri Pangan. 1(22): 46-5

Sahlan, M., A. Devina, D. K. Pratami, H. Situmorang, S. Farida, A. Munim, B. Kusumoputro, M. Yohda, A. Faried, M. Gozan, dan M. Ledyawati. 2018. Antiinflammatory activity of Tetragronula species from Indonesia. Saudi Journal of Biological Sience.

Shortt, C. 1999. The probiotic century: historical and current perspectives. Review on Trend Food Science and Technology (10): 411-417.

Soetan, K.O., M.A. Cyekunl O.O. Aiyelaagbe, dan M.A. Fafunso. 2006. Evaluation of antimicrobial activity of saponins extract of Sorghum bicolor L. Moench. Afr.J. Biotechnol. Vol. pp 2405-2407.

Sohail, A., M. S. Turner, E. K. Prabawati, A. G. A. Coombes, B. Bhandari. Evaluation of Lactobacillus rhamnosus GG and Lactobacillus acidophilus NCFM encapsulated using a novel impinging aerosol method in fruit juice products. International Journal Food Microbiol. 2012, 157, 162-166 
Sudarmadji. S., B, Haryono, dan Suhardi. 1996. Analisa Bahan Makanan dan Pertanian. Liberty

Yogyakarta.

Sujaya, I.N., Y. Ramona, K. A. Nocianitri dan W. R. Aryanta. 2010. Pengembangan Lactobacillus sp F213 Sebagai Probiotik Endogen Indonesia untuk Menangani Traveller's Diarrhea. Laporan Penelitian. Universitas Udayana, Bali.

Sujaya, I. N., I. D. M. Sukrama, K. A. Nocianitri dan W. R. Aryanta. 2012. Ketahanan Probiotik Lactobacillus sp. F213 pada Saluran Pencernaan dan Kemampuannya Menurunkan Kadar Kolesterol Darah. Laporan Penelitian. Universitas Udayana, Bali

Sun, Y. dan Cheng, J.J. (2005). Dilute acid pretreatment of rye straw and bermudagrass for ethanol production. Journal of Bioresource Technology 96: 1599-1606.

Suryani, Y., A. B. Oktavia dan S. Umniyati. 2010. Isolasi dan Karakterisasi Bakteri Asam Laktat dari Limbah Kotoran Ayam sebagai Agensi Probiotik dan Enzim Kolesterol Reduktase. Biologi dan Pengembangan Profesi Pendidik Biologi. Biota. 12 (3): 177-185.

Vijaylakshmi, P. dan R. Radha. 2015. Citrus maxima. The Journal of Phytopharmacology. 5 (4): 263267.
Vinothini R, dan L. Growhter. 2016. Antimicrobialand Phytochemical Analysis of Methanolic and Aqueous Extract of Annona muricata (Leaf and Fruit). International Journal of Current Microbiology and Applied Sciences. Vol 5 No 10. pp 617625.

Zaika, L. L. dan J. C. Kissinger. 1981. Inhibitory and Stimulatory Effects of Oregano on Lacfobacillus Plantarum and Pediococcus Cerevisiae. Journal of Food Science. Vol 46 
